\title{
Life without light: microbial diversity and evidence of sulfur- and ammonium-based chemolithotrophy in Movile Cave
}

\author{
Yin Chen ${ }^{1,5}$, Liqin $\mathrm{Wu}^{2,5}$, Rich Boden ${ }^{1}$, Alexandra Hillebrand ${ }^{3}$, Deepak Kumaresan ${ }^{1}$, \\ Hélène Moussard ${ }^{1}$, Mihai Baciu ${ }^{4}$, Yahai Lu$^{2}$ and J Colin Murrell ${ }^{1}$ \\ ${ }^{1}$ Department of Biological Sciences, University of Warwick, Coventry, UK; ${ }^{2}$ College of Resources and \\ Environmental Sciences, China Agricultural University, Beijing, China; ${ }^{3}$ Institute of Speleology 'Emil \\ Racovita', Bucharest, Romania and ${ }^{4}$ The Group of Underwater and Speleological Exploration, Bucharest, \\ Romania
}

\begin{abstract}
Microbial diversity in Movile Cave (Romania) was studied using bacterial and archaeal 16S rRNA gene sequence and functional gene analyses, including ribulose-1,5-bisphosphate carboxylase/ oxygenase (RuBisCO), soxB (sulfate thioesterase/thiohydrolase) and amoA (ammonia monooxygenase). Sulfur oxidizers from both Gammaproteobacteria and Betaproteobacteria were detected in 16S rRNA, soxB and RuBisCO gene libraries. DNA-based stable-isotope probing analyses using ${ }^{13} \mathrm{C}$-bicarbonate showed that Thiobacillus spp. were most active in assimilating $\mathrm{CO}_{2}$ and also implied that ammonia and nitrite oxidizers were active during incubations. Nitrosomonas spp. were detected in both 16S rRNA and amoA gene libraries from the 'heavy' DNA and sequences related to nitriteoxidizing bacteria Nitrospira and Candidatus 'Nitrotoga' were also detected in the 'heavy' DNA, which suggests that ammonia/nitrite oxidation may be another major primary production process in this unique ecosystem. A significant number of sequences associated with known methylotrophs from the Betaproteobacteria were obtained, including Methylotenera, Methylophilus and Methylovorus, supporting the view that cycling of one-carbon compounds may be an important process within Movile Cave. Other sequences detected in the bacterial 16S rRNA clone library included Verrucomicrobia, Firmicutes, Bacteroidetes, alphaproteobacterial Rhodobacterales and gammaproteobacterial Xanthomonadales. Archaeal 16S rRNA sequences retrieved were restricted within two groups, namely the Deep-sea Hydrothermal Vent Euryarchaeota group and the Miscellaneous Crenarchaeotic group. No sequences related to known sulfur-oxidizing archaea, ammonia-oxidizing archaea, methanogens or anaerobic methane-oxidizing archaea were detected in this clone library. The results provided molecular biological evidence to support the hypothesis that Movile Cave is driven by chemolithoautotrophy, mainly through sulfur oxidation by sulfur-oxidizing bacteria and reveal that ammonia- and nitrite-oxidizing bacteria may also be major primary producers in Movile Cave.
\end{abstract}

The ISME Journal (2009) 3, 1093-1104; doi:10.1038/ismej.2009.57; published online 28 May 2009

Subject Category: microbial ecology and functional diversity of natural habitats

Keywords: Movile Cave; DNA stable-isotope probing; sulfur-oxidizing bacteria; ammonia-oxidizing bacteria

\section{Introduction}

It is generally believed that all the terrestrial and aquatic environments are based on energy and organic carbon that ultimately originated from photosynthesis, that is, by converting light energy into chemical energy used to fix carbon dioxide from the atmosphere. One of the few exceptions are deep-sea hydrothermal vents (reviewed by

Correspondence: JC Murrell, Department of Biological Sciences, University of Warwick, Coventry, CV4 7AL, UK.

E-mail: J.C.Murrell@warwick.ac.uk

${ }^{5}$ These authors contribute equally to this work.

Received 11 February 2009; revised 8 April 2009; accepted 8

April 2009; published online 28 May 2009
Nakagawa and Takai, 2008), in which chemoautotrophic bacteria that gain energy from the oxidation of chemicals such as sulfur and hydrogen are the primary producers. Other exceptions are cave ecosystems, such as Movile Cave (Romania). Unlike deep-sea hydrothermal vents, Movile Cave is located a few kilometers from the Black Sea coast. It is a unique groundwater ecosystem in that: (a) the atmosphere is rich in hydrogen sulfide, carbon dioxide and a substantial amount of methane; (b) the redox potential of the cave water $(\mathrm{pH}=7.5)$ is low and it contains reduced compounds such as sulfide $(0.2-0.3 \mathrm{mM})$, ammonium $(0.2-0.3 \mathrm{mM})$ and methane (0.02 mM) (Sarbu, 2000). The cave is isolated from the outside world and earlier studies 
have implied that this unique ecosystem is exclusively based on chemosynthesis, mainly by sulfur oxidation and methane oxidation (Sarbu et al., 1996; Sarbu, 2000).

Movile Cave is unusual for its high productivity and fauna richness. Characterization of invertebrates has been carried out and 48 terrestrial and aquatic species have been identified, of which 33 are endemic (Sarbu, 2000). However, microbial diversity in this cave has not been studied in detail. Earlier microscopic observations have suggested that filamentous sulfur oxidizers and fungi were abundant in the microbial mat (Sarbu et al., 1994). Later, Vlasceanu et al., (1997) isolated a Thiobacillus thioparus strain, which is particularly abundant in the microbial mat and the activity of ribulose-1,5bisphosphate carboxylase/oxygenase (RuBisCO), a key enzyme in $\mathrm{CO}_{2}$ fixation for many chemoautotrophs, has been detected for this organism (Sarbu et al., 1994). Although sulfur oxidizers are thought to be the major primary producers in Movile Cave (Sarbu et al., 1996; Rohwerder et al., 2003), the presence of up to $1.5 \%$ (v/v) methane in the cave atmosphere suggested that methanotrophs may also be present. Hutchens et al., (2004) used DNA stable-isotope probing (DNA-SIP) to analyze the methanotroph populations and a diverse range of methanotrophs belonging to Alphaproteobacteria and Gammaproteobacteria were identified.

In this study, culture-independent analyses using $16 \mathrm{~S}$ rRNA gene sequences for bacteria and archaea were carried out to determine the microbial diversity present in this unique cave system. Analyses were also carried out using the RuBisCO gene as a functional gene marker for many chemoautotrophs, $\operatorname{sox} B$ (sulfate thioesterase/ thiohydrolase) for sulfur oxidizers, which have the Sox-dependent sulfur oxidation pathway and amoA (ammonia monooxygenase) for ammonia oxidizers. SIP incubations with ${ }^{13} \mathrm{C}$-bicarbonate were also carried out to detect active $\mathrm{CO}_{2}$-fixing bacteria in the cave.

\section{Materials and methods}

Environmental sampling and DNA extraction

Movile Cave water and mat samples were collected in September 2007. The $\mathrm{pH}$ of the water was 7.5. The samples were kept at $4{ }^{\circ} \mathrm{C}$ until they were shipped to the University of Warwick (UK) for further processing. A total of $50 \mathrm{ml}$ water samples (which includes $\sim 1$ g floating microbial mat), well mixed by vortexing, were pelleted by centrifugation, and DNA was extracted using a method described earlier (Neufeld et al., 2007), and then stored at $-20{ }^{\circ} \mathrm{C}$ for later analyses.

\section{PCR, cloning and restriction length fragment polymorphism analyses}

Bacterial 16S rRNA genes were amplified using the 27F/1492R primer set (Lane, 1991). In total, 96 clones were randomly selected from this library and were sequenced using the primer 341F. Archaeal $16 S$ rRNA genes were amplified using a semi-nested approach, with Arch21F/1492R (Delong, 1992) for the first round and Arch21F/Arch958R for the second round (Delong, 1992). The clones were randomly selected and analyzed by RFLP analysis using MspI. Representative clones from each operational taxonomic unit were sequenced. Crude DNA was also used as template to amplify $\operatorname{amo} A, \operatorname{sox} B$, form I RuBisCO (green-like and red-like) and form II RuBisCO genes. The primers used are listed in Table 1. In total, 48 clones from each library were randomly selected and sequenced using the M13F/ M13R primers. All PCR products were cloned into the pCRTOPO2.1 plasmid using the Invitrogen TOPO TA Cloning Kit (Invitrogen, Paisley, UK).

Table 1 Oligonucleotides used in this study

\begin{tabular}{|c|c|c|c|}
\hline Oligonucleotides & Sequences $\left(5^{\prime}-3^{\prime}\right)$ & Target & References \\
\hline $27 \mathrm{~F}$ & AGAGTTTGATCMTGGCTCAG & Bacterial 16S rRNA gene & Lane, 1991 \\
\hline $1492 \mathrm{R}$ & TACGGYTACCTTGTTACGACTT & & \\
\hline $341 \mathrm{~F}$ & CCTACGGGAGGCAGCAG & For sequencing of bacterial 16S rRNA gene & Muyzer et al. (1993) \\
\hline Arch21F & TTCCGGTTGATCCYGCCGGA & Archaeal 16S rRNA gene & Delong, 1992 \\
\hline Arch958R & YCCGGCGTTGAMTCCAATT & & \\
\hline soxB693F & ATCGGNCARGCNTTYCCNTA & $\operatorname{sox} B$ & Meyer et al. (2007) \\
\hline soxB1446R & CATGTCNCCNCCRTGYTG & & \\
\hline amoA1F & GGGGTTTCTACTGGTGGT & Bacterial amoA & Rotthauwe et al. (1997) \\
\hline amoA2R & CCCCTCKGSAAAGCCTTCTTC & & \\
\hline Arch-amoAF & STAATGGTCTGGCTTAGACG & Archaeal $a m o A$ & Francis et al. (2005) \\
\hline Arch-amoAR & GCGGCCATCCATCTGTATGT & & \\
\hline cbbLR1F & AAGGAYGACGAGAACATC & Form I RuBisCO, red form & Selesi et al. (2005) \\
\hline cbbLR1R & TCGGTCGGSGTGTAGTTGAA & & \\
\hline cbbLG1F & GGCAACGTGTTCGGSTTCAA & Form I RuBisCO, green form & Selesi et al. (2005) \\
\hline cbbLG1R & TTGATCTCTTTCCACGTTTCC & & \\
\hline cbbMf & ATCATCAARCCSAARCTSGGCCTGCGTCCC & Form II RuBisCO & Giri et al. (2004) \\
\hline cbbMr & MGAGGTGACSGCRCCGTGRCCRGCMCGRTG & & \\
\hline
\end{tabular}




\section{SIP}

Time-course SIP incubations were carried out. In total, $20 \mathrm{ml}$ of well-mixed cave water and mat sample were put in $120 \mathrm{ml}$ serum vials and incubated for 1 and 3 weeks, respectively, with ${ }^{13} \mathrm{C}$ sodium bicarbonate (Cambridge Isotope Laboratories, Hook, UK, ${ }^{13} \mathrm{C}>99 \%$ ). A control was set up for each microcosm in exactly the same way except that ${ }^{12} \mathrm{C}$ sodium bicarbonate was used. Sodium bicarbonate was added to a final concentration of $0.5 \mathrm{mM}$ at day 1 of each week for each microcosm. The headspace contained regular air and no attempts were made to adjust the headspace air to that of in situ conditions. Owing to the production of ${ }^{12} \mathrm{C}-\mathrm{CO}_{2}$ from heterotrophs present in the samples (data not shown), the incorporation of ${ }^{13} \mathrm{C}$ carbon was not measured. After incubation, cells and mat material were pelleted by centrifugation and DNA was extracted according to the protocol described earlier (Neufeld et al., 2007). Ultracentrifugation, fractionation and DNA precipitation were carried out according to the procedure described by Chen et al., (2008). The 'heavy' ${ }^{13} \mathrm{C}$-labelled DNA from the 1-week incubation (time point 1) and 3-week incubations (time point 2) was used as template to amplify $16 \mathrm{~S}$ rRNA genes from bacteria. A clone library for amoA of bacteria was also constructed using the 'heavy' DNA from 3-week incubations. A total of 48 clones from each library were randomly picked up and sequenced.

\section{DNA sequencing and phylogenetic analyses}

DNA sequencing was carried by cycle sequencing with the BigDye Terminator Cycle Sequencing Kit (PE Applied Biosystems, Warrington, UK) using a 3730A automated sequencing system (PE Applied Biosystems). Bacterial and Archaeal 16S rRNA gene sequences were aligned using the ARB program (Ludwig et al., 2004) and functional genes were aligned using the ClustalX program (Thompson et al., 1997). Phylogenetic and bootstrap analyses were carried out using the Phylowin program (Galtier et al., 1996). Nucleotide sequences from this study were deposited in the GenBank database under the accession numbers FJ604604-FJ604848.

\section{Results}

Microbial diversity in Movile Cave as assessed by $16 S$ rRNA gene clone libraries

To investigate the microbial diversity in Movile Cave, a 16S rRNA clone library for bacteria and archaea, respectively, was constructed and 96 clones were randomly selected and analyzed. The results are summarized in Table 2 and Figures 1-3.

$16 \mathrm{~S}$ rRNA sequences related to known sulfuroxidizing bacteria were detected in the crude DNA (Figure 1). These were classified into Betaproteobacteria (Thiobacillus, three clones), Gammaproteo- bacteria (Thiovirga, seven clones; Thiothrix, one clone; Thioploca, 17 clones) and Epsilonproteobacteria (Sulfuricurvum, one clone). Sequences related to sulfur reducers (Desulfobulbaceae) and denitrifiers (Denitratisoma) were also found (Figure 2). No sequences related to known methanotrophs were detected in the crude DNA. However, a number of $16 \mathrm{~S}$ rRNA gene sequences were associated with known methylotrophs within the Betaproteobacteria (Table 2), including Methylotenera (15 clones), Methylophilus (three clones) and Methylovorus (three clones). Other sequences detected include Verrucomicrobia (one clone), Firmicutes (two clones), Bacteroidetes (15 clones), Alphaproteobacteria from the Rhodobacterales (two clones) and Gammaproteobacteria from the Xanthomonadales (seven clones).

The archaeal 16S rRNA genes sequences were clustered into two major groups (Figure 3). In total, 48 16S rRNA gene clones were classified in the DHVE1 (Deep-sea Hydrothermal Vent Euryarchaeota; Takai and Horikoshi, 1999) group. A total of 42 clones were associated with the MCG (Miscellaneous Crenarchaeotic group; Inagaki et al., 2003) however, these only showed moderate identity $(\sim 92 \%)$ to the $16 \mathrm{~S}$ rRNA gene sequences from MCG. Among those, an uncultured Crenarchaeota clone (B10), which was retrieved from the water column of a sulfurous karstic lake in Spain, was the closest BLAST (http://blast.ncbi.nlm.nih.gov/ Blast.cgi) match (Lliros et al., 2008). It is to be noted that no sequences related to known sulfur-oxidizing archaea, ammonia-oxidizing archaea, methanogens or anaerobic methane-oxidizing archaea were detected in this $16 \mathrm{~S}$ rRNA gene clone library.

\section{Diversity of RuBisCO genes}

The diversity of RuBisCO genes was analyzed using three separate primer sets targeting form I greenlike, form I red-like and form II RuBisCO genes. Results are shown in Figure 4. It is to be noted that all of the sequences from the form I RuBisCO (red type) clone library showed $<90 \%$ identity to sequences in the GenBank database and they formed two separate groups. In total, 30 clones were related ( $\sim 88 \%$ identity) to the RuBisCO genes from Rhodobacter azotoformans and Labrenzia aggregate. The other two sequences were related $(84 \%$ identity) to the RuBisCO gene from Methylibium petroleiphilum.

Similarly, all the clones from the form I green type RuBisCO clone library showed $<90 \%$ identity to sequences in the GenBank database. They were reasonably closely related (85-88\% identity) to the RuBisCO gene sequences from Thiobacillus denitrificans and T. thioparus.

The sequences from the form II RuBisCO clone library fell into two clades. In total, 11 clones had $92 \%$ identity to the form II RuBisCO gene from T. denitrificans and the other 25 clones were most closely related ( $97 \%$ identity) to the RuBisCO gene 
Table 2 Classification by the RDP Classifier of $16 \mathrm{~S}$ rRNA genes retrieved from Movile Cave crude DNA and 'heavy' DNA from ${ }^{13} \mathrm{CO}_{2}-\mathrm{SIP}$ incubations

\begin{tabular}{|c|c|c|c|}
\hline Phylum/order & Crude DNA & Time point $1,{ }^{13} \mathrm{C}-\mathrm{CO}_{2}$ & Time point $2,{ }^{13} \mathrm{C}-\mathrm{CO}_{2}$ \\
\hline Verrucomicrobia & 1 & & \\
\hline Firmicutes & 2 & 2 & \\
\hline Bacteroidetes & 15 & 2 & 1 \\
\hline Planctomycetes & & 1 & 2 \\
\hline Spirochetes & & 1 & 1 \\
\hline Nitrospira & & 2 & \\
\hline Proteobacteria & 63 & 34 & 42 \\
\hline \multicolumn{4}{|l|}{ Alpha } \\
\hline Caulobacterales & & & Brevundimonas (3) \\
\hline Rhodospirillales & & Unclassified Rhodospirillales (1) & Unclassified Acetobacteraceae (1) \\
\hline Rhodobacterales & $\begin{array}{c}\text { Rhodobacter (1) } \\
\text { Unclassified Rhodobacteraceae (1) }\end{array}$ & Unclassified Rhodobacteraceae (1) & $\begin{array}{c}\text { Unclassified Rhodospirillales (1) } \\
\text { Hyphomonas (1) } \\
\text { Roseovarius (1) }\end{array}$ \\
\hline Sphingomonadales & & Unclassified Sphingomonadaceae (3) & Sphingopyxis (1) \\
\hline Rhizobiales & & Unclassified Rhizobiales (3) & Devosia (1) \\
\hline \multicolumn{4}{|l|}{ Beta } \\
\hline Burkholderiales & & $\begin{array}{l}\text { Unclassified Incertae sedis } 5 \text { (2) } \\
\text { Unclassified Burkholderiales (1) }\end{array}$ & $\begin{array}{l}\text { Unclassified Comamonadaceae (1) } \\
\text { Unclassified Incertae sedis } 5 \text { (4) }\end{array}$ \\
\hline Hydrogenophilales & Thiobacillus (3) & Thiobacillus (3) & Thiobacillus (4) \\
\hline Rhodocyclales & Denitratisoma (1) & Unclassified Rhodocyclaceae (4) & Dechloromonas (1) \\
\hline Methylophilales & $\begin{array}{l}\text { Methylotenera (15) } \\
\text { Methylophilus (3) } \\
\text { Methylovorus (3) }\end{array}$ & & \\
\hline Nitrosomonadales & & Nitrosomonas (1) & Nitrosomonas (4) \\
\hline Unclassified & & Thiobacter (8) & Candidatus 'Nitrotoga arctica' (13) \\
\hline Betaproteobacteria & & & Methyloversatilis (1) \\
\hline \multicolumn{4}{|l|}{ Gamma } \\
\hline Chromatiales & Thiovirga (7) & & Thiovirga (1) \\
\hline Xanthomonadales & $\begin{array}{c}\text { Aquimonas (6) } \\
\text { Aquimos }\end{array}$ & Unclassified Xanthomonadaceae (1) & Aquimonas (2) \\
\hline Thiotrichales & Thiothrix (1) & Thioploca (1) & \\
\hline & Thioploca (17) & Unclassified Thiotrichaceae (2) & \\
\hline & Unclassified Thiotrichaceae (2) & & \\
\hline \multicolumn{4}{|l|}{ Epsilon } \\
\hline Myхососcales & Byssovorax (1) & Unclassified Myхососcales (2) & \\
\hline Desulfobacterales & Unclassified Desulfobulbaceae (1) & & Unclassified Desulfobulbaceae (1) \\
\hline Campylobacterales & Sulfuricurvum (1) & & \\
\hline Unclassified bacteria & 4 & 4 & 1 \\
\hline Total & 85 & 46 & 47 \\
\hline
\end{tabular}

Abbreviations: RDP, Ribosomal Database Project; SIP, stable isotope probing.

from Halothiobacillus neapolitanus, but they clearly formed a separate branch as supported by bootstrap analyses.

Diversity of soxB and amo $A$ genes

On phylogenetic analysis, it was obvious that the sox $B$ genes retrieved were distributed throughout the Alphaproteobacteria, Betaproteobacteria and Gammaproteobacteria (Figure 5). Within the Betaproteobacteria, four clones were closely related to Thiobacillus and two clones were related to the sox $B$ homolog from $M$. petroleiphilum. Within the Gammaproteobacteria, five clones were related to sox $B$ genes from Thiothrix and the other 10 clones showed only $65 \%$ identity to $s o x B$ genes from Halothiobacillus species.

amoA genes from bacteria formed two separate clades: two clones were within the Nitrosomonas europaea clade and the other 45 clones grouped within the Nitrosomonas oligotropha clade (Figure 6). Using crude DNA as template with primers for $a m o A$ genes from archaea did not yield any PCR products of the expected sizes.

SIP analyses using ${ }^{13} \mathrm{C}$-bicarbonate

To investigate microorganisms which were active in assimilating $\mathrm{CO}_{2}$ in Movile Cave, SIP incubations were carried out using ${ }^{13} \mathrm{C}$-bicarbonate. 


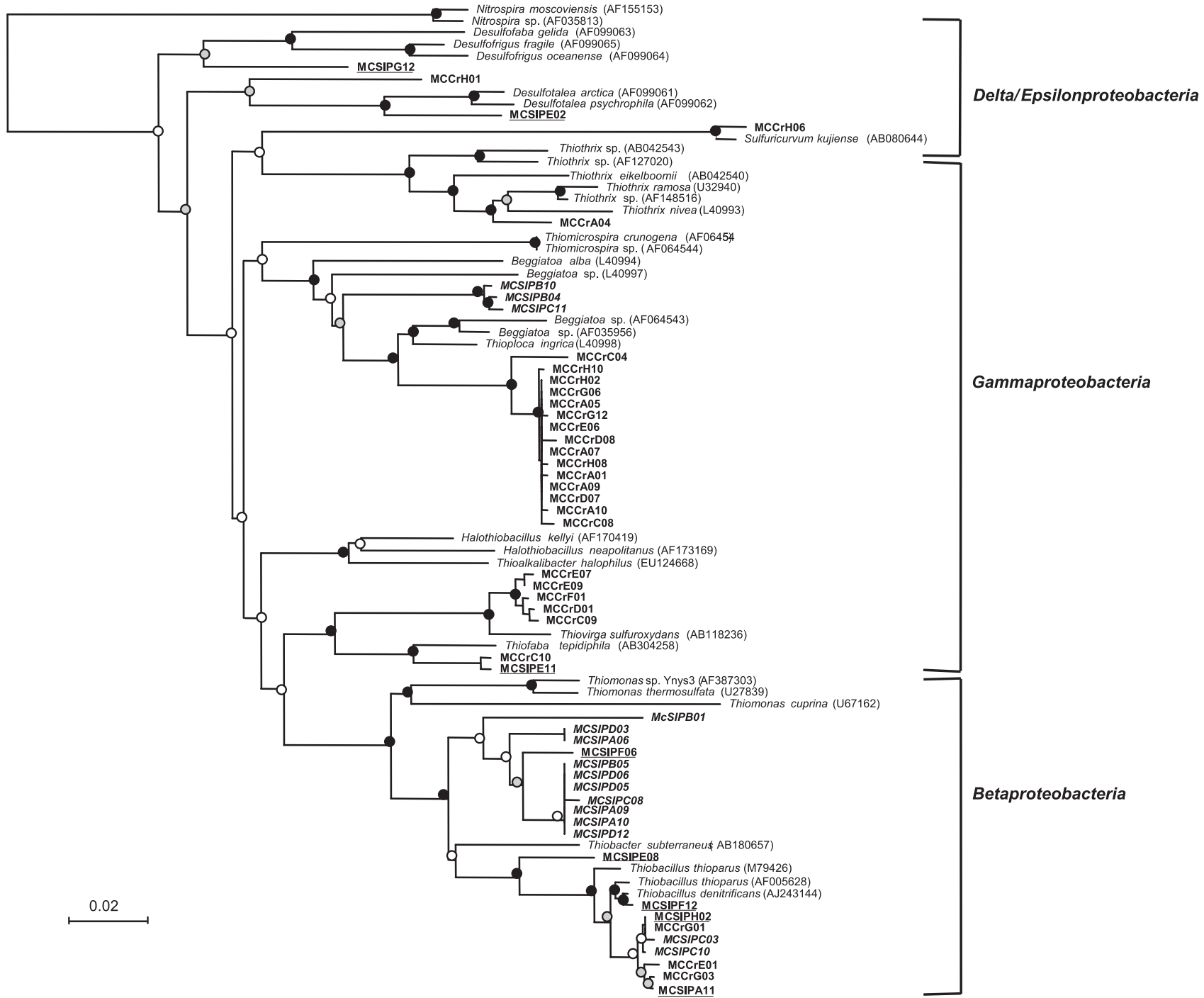

Figure 1 Neighbor-joining phylogenetic tree of bacterial 16S rRNA sequences related to known sulfur-oxidizing and sulfur-reducing bacteria. Sequences were aligned using the ARB program and the tree was constructed by Phylowin (556 bp). Bootstrap values are indicated as blank circles $(<50 \%)$, gray circles $(50-75 \%)$ and black circles $(>75 \%)$. Sequences in bold were retrieved from the crude DNA; sequences in bold and italic were retrieved from 'heavy' DNA of the 1-week incubation with ${ }^{13} \mathrm{C}$-bicarbonate; sequences in bold and underlined were retrieved from 'heavy' DNA of the 3-week incubation with ${ }^{13} \mathrm{C}$-bicarbonate.

A bacterial 16S rRNA clone library was constructed using the 'heavy' DNA extracted after a 1-week incubation and a 3-week incubation, respectively. The results are presented in Table 2 and Figure 1.

After 1 week of incubation with ${ }^{13} \mathrm{C}$-bicarbonate, it was found that sulfur-oxidizing bacteria from both the Betaproteobacteria (Thiobacillus, three clones; Thiobacter, eight clones) and Gammaproteobacteria (Thioploca, one clone; unclassified Thiotrichaceae, two clones) were labeled with ${ }^{13} \mathrm{C}$. Sulfuricurvumrelated 16S rRNA gene sequences were not found, although they were found in the 16S rRNA gene library constructed with crude DNA. It is interesting to note that $16 \mathrm{~S}$ rRNA gene sequences related to ammonia-oxidizing bacteria (Nitrosomonas, one clone) and nitrite-oxidizing bacteria (Nitrospira, two clones) were present after 1-week incubation with ${ }^{13} \mathrm{C}$-bicarbonate. After 3 weeks of incubation with ${ }^{13} \mathrm{C}$-bicarbonate, sulfur-oxidizing bacteria were still present, including Thiobacillus (four clones), Thiovirga (one clone). Four 16S rRNA clones were associated with the ammonia-oxidizing bacterium Nitrosomonas and 13 clones showed high identity to the 16S rRNA from Candidatus 'Nitrotoga arctica', a novel nitrite-oxidizing bacterium isolated from the Siberian Arctic (Alawi et al., 2007).

A number of $16 \mathrm{~S}$ rRNA sequences in the 'heavy' DNA clone library were associated with the Alphaproteobacteria, including Rhodospirillales, Rhodobacterales and Sphingomonadales. A few sequences related to Bacteroidetes, Planctomycetes and Spirochetes were also found in the 'heavy' DNA from both the 1-week and the 3-week incubations 


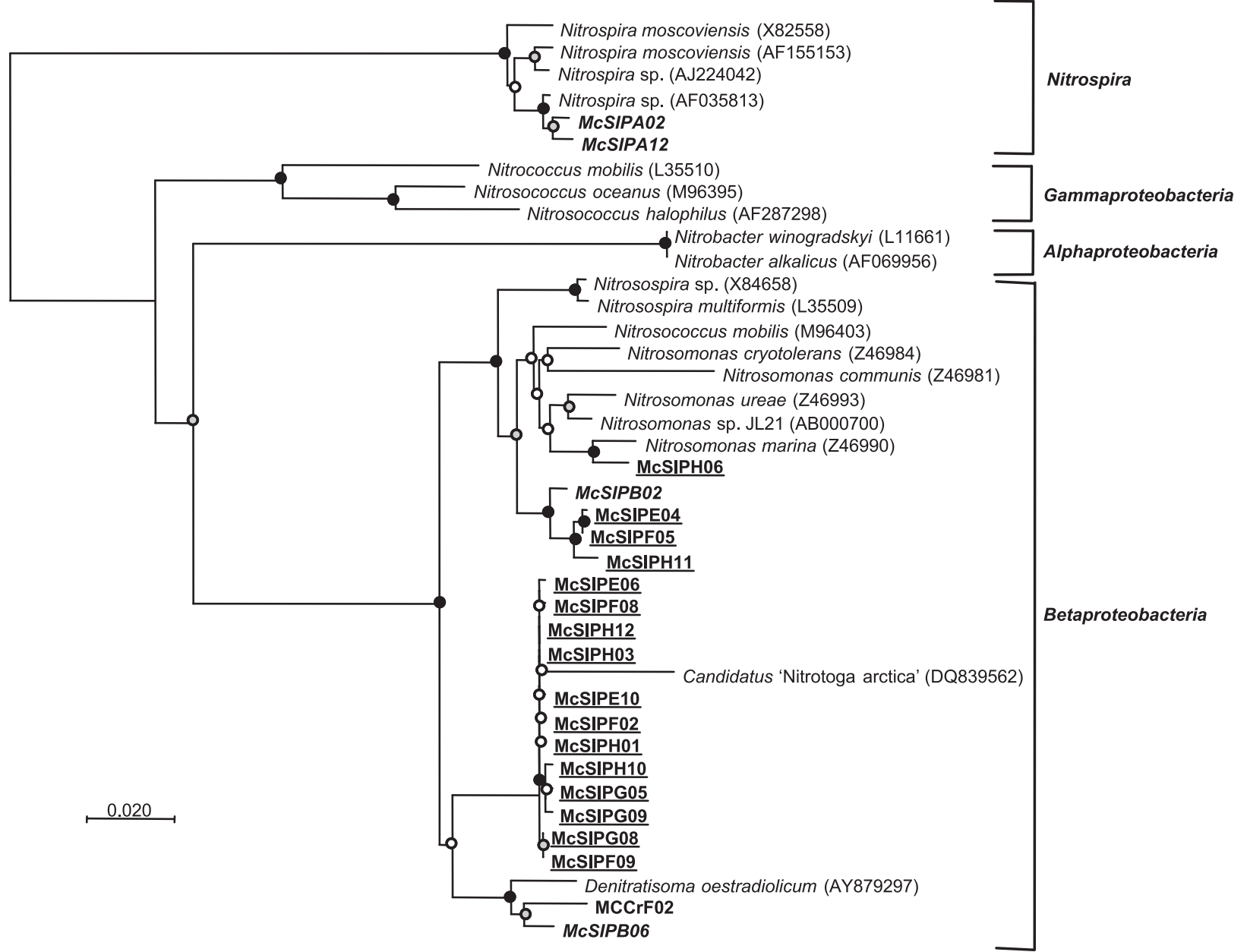

Figure 2 Neighbor-joining phylogenetic tree of bacterial 16S rRNA sequences related to known ammonium- and nitrite-oxidizing bacteria and denitrifying bacteria. Sequences were aligned using the ARB program and the tree was constructed by Phylowin (672 bp). Bootstrap values are indicated as blank circles $(<50 \%)$, gray circles $(50-75 \%)$ and black circles $(>75 \%)$. Sequences in bold were retrieved from the crude DNA; sequences in bold and italic were retrieved from 'heavy' DNA of the 1-week incubation with ${ }^{13} \mathrm{C}$-bicarbonate; sequences in bold and underlined were retrieved from 'heavy' DNA of the 3-week incubation with ${ }^{13} \mathrm{C}$-bicarbonate.

with ${ }^{13} \mathrm{C}$-bicarbonate. Sequences related to Aquimonas were also found in the DNA from the 3-week SIP incubation microcosm.

A clone library of amoA genes from bacteria was constructed using the 'heavy' DNA from the 3-week incubation with ${ }^{13} \mathrm{C}$-bicarbonate. In total, 26 amo $A$ clones clustered in the $N$. europaea amo $A$ clade and the other 21 clones were associated with the $N$. oligotropha clade. It was not possible to amplify amo $A$ genes from archaea using the 'heavy' DNA as template.

\section{Discussion}

It has been hypothesized earlier that the Movile Cave system is driven by chemoautotrophy (Sarbu and Kane, 1995; Sarbu et al., 1996; Sarbu, 2000). The cave continuously receives a high flow rate of hydrothermal water rich in sulfide and methane (Sarbu, 2000) and sulfur oxidation was thought to be the major energy source for primary production (Sarbu et al., 1996). Earlier analyses showed that aerobic methanotrophs were also present in this cave, suggesting that methanotrophy could also be one of the major primary production processes (Hutchens et al., 2004; Sarbu, 2000). Although the cave water contains high concentrations of ammonium (0.28 mM, Sarbu, 2000), nitrification as a major energy production route has not been investigated earlier. It has, however, been observed that nitrogen in the microbial mat is isotopically lighter $\left(\delta^{15} \mathrm{~N}=-9.1 \%\right.$ o $)$ than ammonium-nitrogen in the cave water $\left(\delta^{15} \mathrm{~N}=+19.9 \%\right.$ o) (Sarbu et al., 1996). Lack of further evidence made it difficult to ascertain whether ammonium uptake by microbes or nitrification was the reason for the observed lighter nitrogen isotope content in the microbial mat. Our DNA-SIP experiment using ${ }^{13} \mathrm{C}$-bicarbonate indicated that ammonia- and nitrite oxidizers were particularly active in the assimilation of ${ }^{13} \mathrm{C}$-labelled $\mathrm{CO}_{2}$ during microcosm incubations, indicating that 


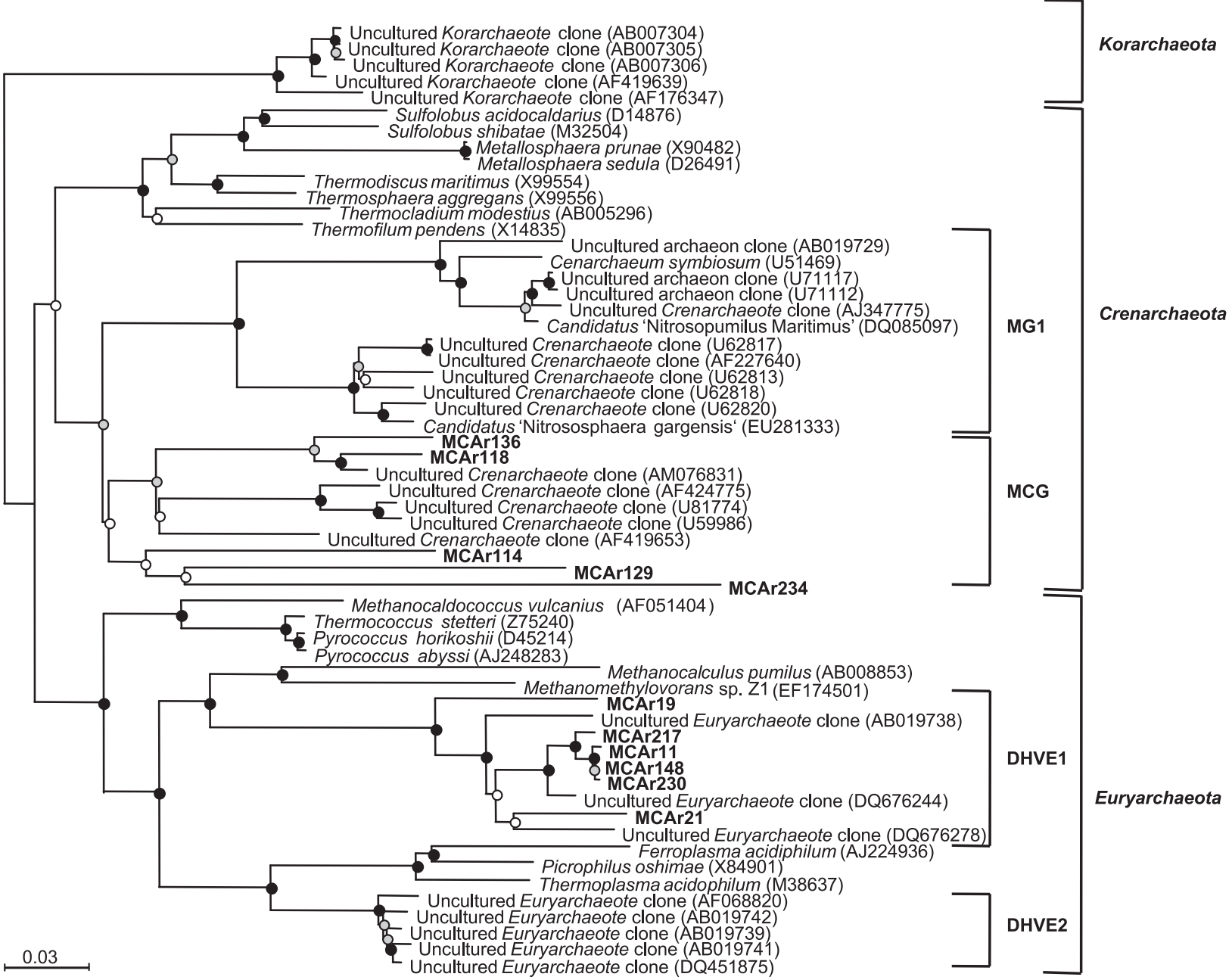

Figure 3 Neighbor-joining phylogenetic tree of archaeal 16S rRNA gene sequences (779 bp) retrieved from Movile Cave crude DNA. Sequences were aligned using the ARB program and the tree was constructed by Phylowin. Bootstrap values are indicated as blank circles $(<50 \%)$, gray circles $(50-75 \%)$ and black circles $(>75 \%)$. Sequences retrieved from the crude DNA are highlighted in bold.

nitrification could at least partially account for the shift of nitrogen isotope content.

Further molecular-based analyses using 16S rRNA and amoA genes showed that Nitrosomonas spp. were responsible for ammonia oxidation and Nitrospira and Candidatus 'Nitrotoga' were probably the major nitrite utilizers. The community of Nitrosomonas in the crude DNA is predominated by bacteria of the $N$. oligotropha clade, whereas more amo $A$ gene sequences from the $N$. europaea clade were seen during SIP incubations (Figure 6). Studies have shown that ammonia availability could select against different Nitrosomonas clades. For example, by studying the ammonia-oxidizing bacterial community in aeration sequencing batch reactors, Otawa et al., (2006) have observed that the $N$. europaea clade were dominant in reactors in which ammonium concentration was higher, whereas bacteria of the $N$. oligotropha clade were dominant in those in which the ammonium concentration was lower. It is also possible that the toxicity of nitrite may affect the relative distribution of these two clades. For example, Limpiyakorn et al., (2007) observed that the $N$. oligotropha clade comprised the majority of ammonia-oxidizing bacterial populations when nitrite did not accumulate, whereas the $N$. europaea clade became dominant when concentrations of nitrite were high $(>2.1 \mathrm{mM})$. The toxic effect of nitrite may explain the increase in the relative abundance of the $N$. europaea clade during SIP incubations. The relative change of ammonium concentration during SIP incubations is probably not as dramatic as that of nitrite because of the presence of relatively high concentrations of ammonium $(\sim 0.3 \mathrm{mM})$ in the Movile Cave water. Temporary accumulation of nitrite may, however, occur during microcosm incubations: this was supported by the appearance of nitrite-oxidizing populations in the 'heavy' DNA during ${ }^{13} \mathrm{C}$-bicarbonate incubations. Clearly, in the future, quantification of ammonium, nitrite and nitrate needs to be followed during SIP incubations to fully understand the 


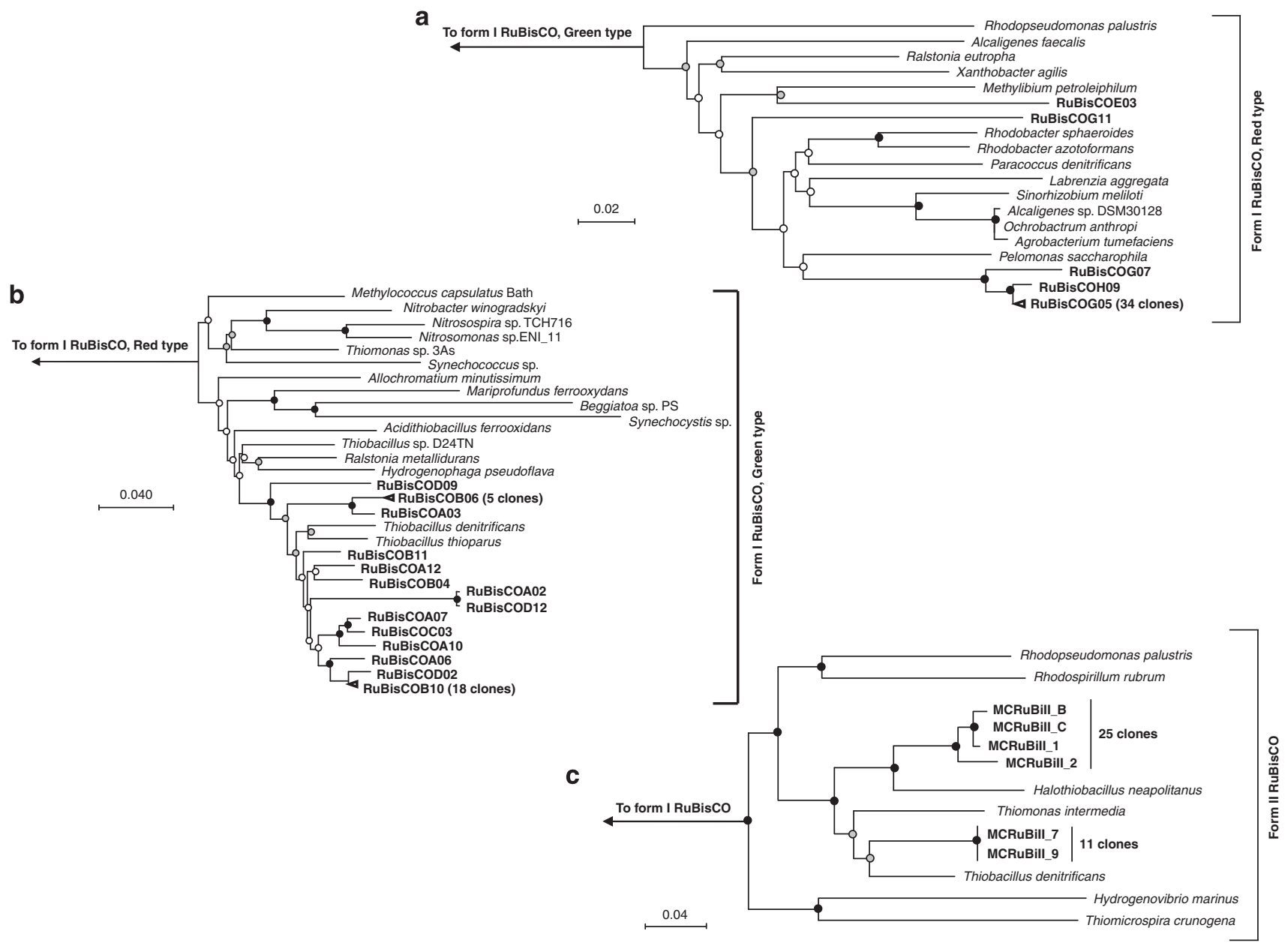

Figure 4 Neighbor-joining phylogenetic trees of form I red-like (430 bp) ribulose-1,5-bisphosphate carboxylase/oxygenase (RuBisCO) (a), form I green-like (571 bp) RuBisCO (b) and form II RuBisCO (238 bp) (c) genes retrieved from Movile Cave crude DNA. Sequences were aligned using the ClustalX program and the trees were constructed by Phylowin. Bootstrap values are indicated as blank circles $(<50 \%)$, gray circles $(50-75 \%)$ and black circles ( $>75 \%)$. Sequences retrieved from the crude DNA are highlighted in bold.

nitrogen cycling in Movile Cave and to establish the link between microbial diversity and activity.

The atmosphere in Movile Cave contains a high concentration of $\mathrm{H}_{2} \mathrm{~S}$ (8-12 $\mathrm{mg} \mathrm{l}^{-1}$ ) and highly diverse sulfur oxidizers inhabit the cave water and form a visible microbial mat. Microscopic observations indicated that the floating mat contained Thiothrix- and Beggiatoa-like filamentous bacteria (Sarbu et al., 1994) and subsequently a T. thioparus strain was isolated from Movile Cave water (Vlasceanu et al., 1997). Earlier studies have shown that aerobic and anaerobic sulfur oxidizers are abundant (up to $10^{7} \mathrm{CFU}$ (colony-forming unit) per gram sample) (Rohwerder et al., 2003). Our molecularbased analyses confirmed the presence of filamentous sulfur-oxidizing bacteria related to Thiothrix, Beggiatoa and Thioploca within the Gammaproteobacteria (Figure 1). The 16S rRNA, soxB (Figure 5) and RuBisCO (Figure 4c) sequences analyses also suggest the presence of a novel group of sulfur-oxidizing Gammaproteobacteria, related to Thiovirga and Thiofaba within the Halothiobacillaceae family (Ito et al., 2005; Mori and Suzuki, 2008).
They are loosely related to Halothiobacillus spp. in terms of $16 \mathrm{~S}$ rRNA gene, soxB gene and RuBisCO gene sequence identities. They are also separated from Thiovirga and Thiofaba by their 16S rRNA identity (Figure 1). 16S rRNA gene sequences related to T. denitrificans and T. thioparus within the Betaproteobacteria were also abundant, which has been suggested earlier (Vlasceanu et al., 1997). This group, compared with the filamentous sulfur oxidizers Thiothrix-Thioploca-Beggiatoa, was particularly active during SIP microcosm incubations. The presence of anaerobic sulfur oxidizers in Movile Cave has also been suggested earlier (Rohwerder et al., 2003) and a 16S rRNA sequence related to Sulfuricurvum was detected in our crude DNA clone library, although it was not labeled during SIP incubations, probably because of the fact that the incubation was carried out aerobically, and Sulfuricurvum oxidizes sulfur anaerobically (Kodama and Watanabe, 2004). It is to be noted that no sequences related to known sulfur-oxidizing archaea were observed in the archaeal 16S RNA clone library, which may reflect the fact that the 


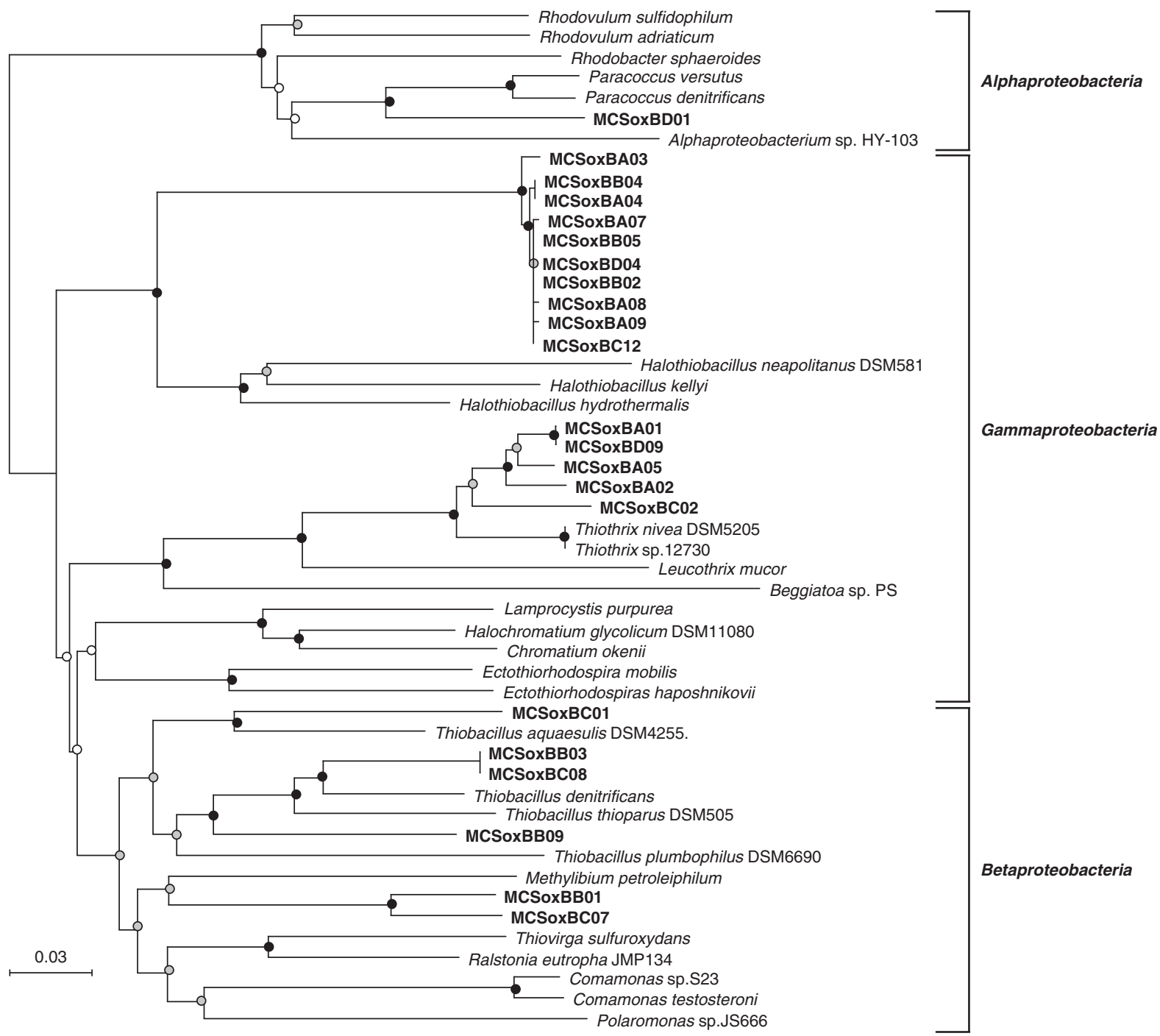

Figure 5 Neighbor-joining phylogenetic tree of $\operatorname{sox} B$ (sulfate thioesterase/thiohydrolase) gene sequences (412 bp) retrieved from Movile Cave crude DNA. Sequences were aligned using the ClustalX program and the tree was constructed by Phylowin. Bootstrap values are indicated as blank circles $(<50 \%)$, gray circles $(50-75 \%)$ and black circles $(>75 \%)$. Sequences retrieved from the crude DNA are highlighted in bold.

temperature in the cave $\left(20^{\circ} \mathrm{C}\right)$ is constant while all known sulfur-oxidizing archaea to date are thermophilic.

One notable difference in the Movile Cave microbial community compared with other chemoautotrophically based cave systems, such as Lower Kane Cave (USA), is that Epsilonproteobacteria were less abundant in Movile Cave (Engel et al., 2003, 2004). However, as with our study, another chemoautotrophically based cave, Frasassi Cave (Italy), was also dominated by Gammaproteobacteria and Betaproteobacteria rather than Epsilonproteobacteria (Macalady et al., 2006). The most recent research on niche differentiation among sulfur-oxidizing bacteria within Frasassi Cave tends to suggest that Epsilonproteobacteria dominated when sulfide to oxygen ratios were high (Macalady et al., 2008). Clearly, more study of Movile Cave is needed to determine the distribution and niche adaption of sulfur oxidizers in the mat, in different depths of the cave water and in biofilms on the surface of the walls of the cave.

The presence of a high relative abundance of methylotroph 16S rRNA gene sequences in the crude DNA, as revealed by molecular analyses, is surprising given the fact that the cave receives a high flux of methane. It is likely that these methylotrophs feed on methanol produced by and released from methanotrophs that are consuming methane. Earlier studies showed high methane oxidation activity in the cave water and floating mats and a variety of methanotrophs have been detected in this cave (Hutchens et al., 2004). In fact, methylotroph-related 16S rRNA sequences were also observed in the 'heavy' DNA from ${ }^{13} \mathrm{C}$-methane incubations and this has been interpreted as cross-feeding of carbon, 


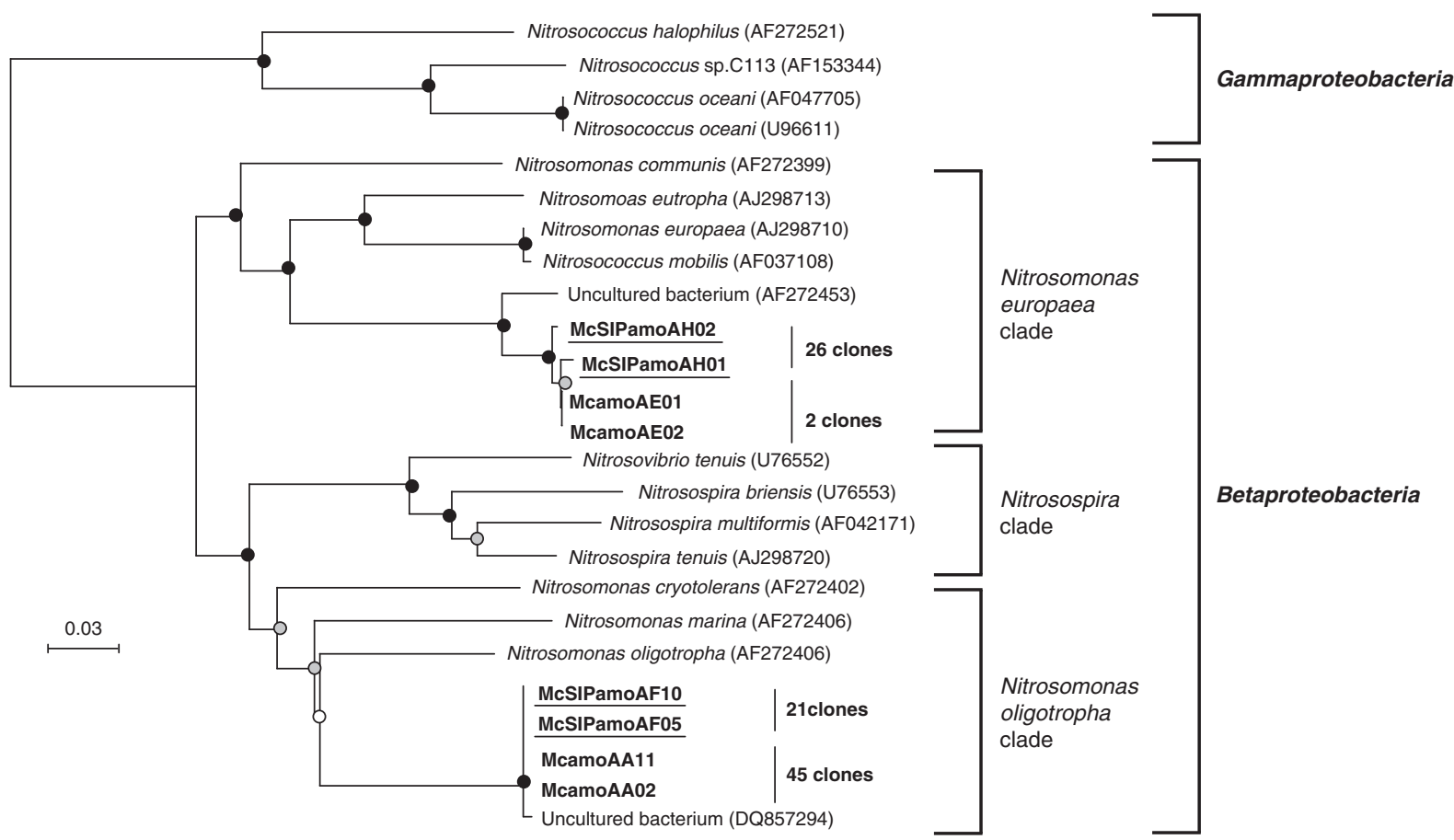

Figure 6 Neighbor-joining phylogenetic tree of bacterial amoA gene sequences (328 bp) retrieved from Movile Cave crude DNA and 'heavy' DNA from the 3-week stable-isotope probing (SIP) incubation with ${ }^{13} \mathrm{C}$-bicarbonate. Sequences were aligned using the ClustalX program and the tree was constructed by Phylowin. Bootstrap values are indicated as blank circles $(<50 \%)$, gray circles $(50-75 \%)$ and black circles $(>75 \%)$. Sequences retrieved from the crude DNA are highlighted in bold and those in bold and underlined were retrieved from 'heavy' DNA of the 3-week incubation with ${ }^{13} \mathrm{C}$-bicarbonate.

presumably methanol or formate, from methanotrophs to methylotrophs (Hutchens et al., 2004). Another possibility is that methanol may come from the degradation of chitin-like substances from cave fauna, as these compounds need to be recycled when cave fauna die, or that the methylotroph sequences that were labeled are in fact from as yet uncultured methanotrophs in the Betaproteobacteria. The methylotrophs were assigned to the Methylophilaceae family (Betaproteobacteria). Sequences related to $M$. petroleiphilum (a facultative methylotroph in the Betaproteobacteria) were also found in the $\operatorname{sox} B$ and RuBisCO clone libraries. An earlier culture-based study also showed that the numbers of culturable methylotrophs in the floating mat were around $10^{6} \mathrm{CFU}$ per gram dry weight of mat (Rohwerder et al., 2003).

Archaeal communities in cave systems, in general, have not been studied in detail. Macalady et al., (2007) showed that the dominant archaea in the wall biofilms from Frasassi Cave (another chemoautotrophy-based cave, but with a low $\mathrm{pH}$ ) were associated with two groups, namely Ferroplasma and an environmental clone group with sequences from acid mine drainage and Yellowstone hot spring. No Crenarchaeota were found in Frasassi Cave. In contrast, the archaeal community in Movile Cave showed some similarity to deep-sea hydrothermal vent environments (Takai and Horikoshi, 1999), but differed from these in that no $16 \mathrm{~S}$ rRNA sequences related to known ammonia-oxidizing archaea were found in our study, and Nitrosomonas spp. were probably the major nitrifiers in Movile Cave, whereas it has been suggested that ammoniaoxidizing Crenarchaea, rather than their bacterial counterparts, are the major nitrifiers in deep-sea vents (Lam et al., 2004; Nakagawa and Takai, 2008). Although it is possible that the clone library had bias because of the imperfect 16S rRNA primers for archaea, as well as bias during SIP incubations, our results imply that bacterial chemolithotrophs are probably the dominant primary producers in Movile Cave.

In addition to $16 \mathrm{~S}$ rRNA analyses, we also used functional marker genes to characterize the microbial diversity in Movile Cave. Great care is needed in the interpretation of the results, as not all chemolithoautotrophs use RuBisCO for $\mathrm{CO}_{2}$ fixation and at least three other $\mathrm{CO}_{2}$ fixation pathways are known (reviewed by Nakagawa and Takai, 2008). Similarly, microorganisms also use a number of different pathways for sulfur oxidation, although the Sox pathway is the most highly characterized (Kelly et al., 1997). Thus, functional gene analyses should always be used in combination with other techniques, such as $16 \mathrm{~S}$ rRNA gene-based methods. In addition, we did not carry out functional gene analyses of $\operatorname{sox} B$ and RuBisCO for 'heavy' DNA from SIP incubations because bacteria, which contain these genes, will also be present in 'light' DNA. 
Furthermore, sox $B$ genes also occur in facultative bacteria that could derive most of their cell carbon from multicarbon sources.

In summary, we have studied the microbial diversity in Movile Cave and suggest that ammonia/nitrite-oxidizing bacteria may also contribute to primary productivity in this cave. Further work on the niche distribution of sulfur and ammonia/nitrite oxidizers, as well as the contribution of one-carbon compound oxidation to primary production, is needed for a full understanding of the sulfur, nitrogen and carbon cycles within Movile Cave.

\section{Acknowledgements}

$\mathrm{L} \mathrm{Wu}$ acknowledges the NERC International Opportunities Fund of the Marine \& Freshwater Microbial Biodiversity Programme. Y Chen was supported by a NERC, Dorothy Hodgkin Postgraduate Award through the University of Warwick. We thank A Simpson, C Gibbs, L Witcomb, $\mathrm{M}$ Stein and $\mathrm{M}$ Bhatti for their help in construction of clone libraries. We greatly acknowledge Prof DP Kelly for his insight and advice on the paper.

\section{References}

Alawi M, Lipski A, Sanders T, Pfeiffer EM, Spieck E. (2007). Cultivation of a novel cold-adapted nitrite oxidizing Betaproteobacterium from the Siberian Arctic. ISME J 1: 256-264.

Chen Y, Dumont MG, Neufeld JD, Bodrossy L, StralisPavese N, McNamara NP et al. (2008). Revealing the uncultured majority: combining DNA stableisotope probing, multiple displacement amplification and metagenomics analyses of uncultivated Methylocystis in acidic peatlands. Environ Microbiol 10: 2609-2622.

Delong EF. (1992). Archaea in coastal marine environments. Proc Natl Acad Sci USA 89: 5685-5689.

Engel AS, Lee N, Porter ML, Stern LA, Bennett PC, Wagner M. (2003). Filamentous 'Epsilonproteobacteria' dominate microbial mats from sulfidic cave springs. Appl Environ Microbiol 69: 5503-5511.

Engel AS, Porter ML, Stern LA, Quinlan S, Bennett PC. (2004). Bacterial diversity and ecosystem function of filamentous microbial mats from aphotic (cave) sulfidic springs dominated by chemolithoautotrophic 'Epsilonproteobacteria'. FEMS Microbiol Ecol 51: 31-53.

Francis CA, Roberts KJ, Beman JM, Santoro AE, Oakley BB. (2005). Ubiquity and diversity of ammoniaoxidizing archaea in water columns and sediments of the ocean. PNAS 102: 14683-14688.

Galtier N, Gouy M, Gautier C. (1996). SeaView and Phylo_win, two graphic tools for sequence alignment and molecular phylogeny. Comput Appl Biosci 12: 543-548.

Giri BJ, Bano N, Hollibaugh JT. (2004). Distribution of RuBisCO genotypes along a redox gradient in Mono Lake, California. Appl Environ Microbiol 70: 3443-3448.
Hutchens E, Radajewski S, Dumont MG, McDonald IR, Murrell JC. (2004). Analysis of methanotrophic bacteria in Movile Cave by stable isotope probing. Environ Microbiol 6: 111-120.

Inagaki F, Suzuki M, Takai K, Oida H, Sakamoto T, Aoki K et al. (2003). Microbial communities associated with geological horizons in coastal subseafloor sediments from the sea of Okhotsk. Appl Environ Microbiol 69: 7224-7235.

Ito T, Sugita K, Yumoto I, Nodasaka Y, Okabe S. (2005). Thiovirga sulfuroxydans gen. nov., sp. nov., a chemolithoautotrophic sulfur-oxidizing bacterium isolated from a microaerobic waste-water biofilm. Int J Syst Evol Microbiol 55: 1059-1064.

Kelly DP, Shergill JK, Lu WP, Wood AP. (1997). Oxidative metabolism of inorganic sulfur compounds by bacteria. Antonie Van Leeuwenhoek 71: 95-107.

Kodama Y, Watanabe K. (2004). Sulfuricurvum kujiense gen. nov., sp. nov., a facultatively anaerobic, chemolithoautotrophic, sulfur-oxidizing bacterium isolated from an underground crude-oil storage cavity. Int $J$ Syst Evol Microbiol 54: 2297-2300.

Lam P, Cowen JP, Jones RD. (2004). Autotrophic ammonia oxidation in a deep-sea hydrothermal plume. FEMS Microbiol Ecol 47: 191-206.

Lane DJ. (1991). 16S/23S rRNA sequencing. In: Stackebrandt E and Goodfellow M (eds) Nucleic Acid Techniques in Bacterial Systematics. John Wiley \& Sons: New York, USA, pp 115-147.

Limpiyakorn T, Kurisu F, Sakamoto Y, Yagi O. (2007). Effects of ammonium and nitrite on communities and populations of ammonia-oxidizing bacteria in laboratory-scale continuous-flow reactors. FEMS Microbiol Ecol 60: 501-512.

Lliros M, Casamayor EO, Borrego C. (2008). High archaeal richness in the water column of a freshwater sulfurous karstic lake along an interannual study. FEMS Microbiol Ecol 66: 331-342.

Ludwig W, Strunk O, Westram R, Richter L, Meier J, Yadhukumar $\mathrm{H}$ et al. (2004). ARB: a software environment for sequence data. Nucleic Acids Res 32: 1363-1372.

Macalady JL, Lyon EH, Koffman B, Albertson LK, Meyer K, Galdenzi S et al. (2006). Dominant microbial populations in limestone-corroding stream biofilms, Frasassi cave system, Italy. Appl Environ Microbiol 72: 5596-5609.

Macalady JL, Jones DS, Lyon EH. (2007). Extremely acidic, pendulous cave wall biofilms from the Frasassi cave system, Italy. Environ Microbiol 9: 1402-1414.

Macalady JL, Dattagupta S, Schaperdoth I, Jones DS, Druschel GK, Eastman D. (2008). Niche differentiation among sulfur-oxidizing bacterial populations in cave waters. ISME J 2: 590-601.

Meyer B, Imhoff JF, Kuever J. (2007). Molecular analysis of the distribution and phylogeny of the $\operatorname{sox} B$ gene among sulfur-oxidizing bacteria - evolution of the Sox sulfur oxidation enzyme system. Environ Microbiol 9: 2957-2977.

Mori K, Suzuki K. (2008). Thiofaba tepidiphila gen. nov., sp. nov., a novel obligate chemolithoautotrophic, sulfur-oxidizing bacterium of the Gammaproteobacteria isolated from a hot spring. Int $J$ Syst Evol Microbiol 58: 1885-1891.

Muyzer G, de Waal EC, Uitterlinden AG. (1993). Profiling of complex microbial populations by denaturing gradient gel electrophoresis analysis of polymerase 
chain reaction-amplified genes coding for $16 \mathrm{~S}$ rRNA. Appl Environ Microbiol 59: 695-700.

Nakagawa S, Takai K. (2008). Deep-sea vent chemoautotrophs: diversity, biochemistry and ecological significance. FEMS Microbiol Ecol 65: 1-14.

Neufeld JD, Schafer H, Cox MJ, Boden R, McDonald IR, Murrell JC. (2007). Stable-isotope probing implicates Methylophaga spp. and novel Gammaproteobacteria in marine methanol and methylamine metabolism. ISME J 1: 480-491.

Otawa K, Asano R, Ohba Y, Sasaki T, Kawamura E, Koyama F et al. (2006). Molecular analysis of ammoniaoxidizing bacteria community in intermittent aeration sequencing batch reactors used for animal wastewater treatment. Environ Microbiol 8: 1985-1996.

Rohwerder T, Sand W, Lascu C. (2003). Preliminary evidence for a sulfur cycle in Movile Cave, Romania. Acta Biotechnol 23: 101-107.

Rotthauwe JH, Witzel KP, Liesack W. (1997). The ammonia monooxygenase structural gene $a m o A$ as a functional marker: molecular fine-scale analysis of natural ammonia-oxidizing populations. Appl Environ Microbiol 63: $4704-4712$.

Sarbu SM, Kinkle BK, Vlasceanu L, Kane TC. (1994). Microbiological characterization of a sulfur-rich groundwater ecosystem. Geomicrobiol J 12: 175-182.
Sarbu SM, Kane TC. (1995). A subterranean chemoautotrophically based ecosystem. NSS Bull 57: 91-98.

Sarbu SM, Kane TC, Kinkle BK. (1996). A chemoautotrophically based cave ecosystem. Science 272: 1953-1955.

Sarbu SM. (2000). Movile Cave: a chemoautotrophically based groundwater ecosystem. In: Wilkens H, Culver DC, Humphreys WF (eds). Subterranean Ecosystems. Elsevier: Amsterdam, pp 319-343.

Selesi D, Schmid M, Hartmann A. (2005). Diversity of green-like and red-like ribulose-1,5-bisphosphate carboxylase/oxygenase large-subunit genes $(c b b L)$ in differently managed agricultural soils. Appl Environ Microbiol 71: 175-184.

Takai K, Horikoshi K. (1999). Genetic diversity of Archaea in deep-sea hydrothermal vent environments. Genetics 152: 1285-1297.

Thompson JD, Gibson TJ, Plewniak F, Jeanmougin F, Higgins DG. (1997). The ClustalX windows interface: flexible strategies for multiple sequence alignment aided by quality analysis tools. Nucleic Acids Res 24: 4876-4882.

Vlasceanu L, Popa R, Kinkle BK. (1997). Characterization of Thiobacillus thioparus LV43 and its distribution in a chemoautotrophically based groundwater ecosystem. Appl Environ Microbiol 63: 3123-3127. 